\title{
Pharmaciana
}

Vol.10, No.2, July 2020, Page. $201-210$

ISSN: 2088 4559; e-ISSN: 24770256

DOI: $10.12928 /$ pharmaciana.v10i2.15658

\section{Risk factors of adverse drug reactions of first-line antiretroviral therapy in HIV patients at RSUD Dr. Moewardi}

\author{
Ana Amalia ${ }^{1,2}$, Fita Rahmawati ${ }^{* 3}$ \\ ${ }^{1}$ Faculty of Pharmacy, Muhammadiyah Surakarta University, \\ Jl. Achmad Yani, Tromol, Pabelan, Kartasura, Gatak, Pabelan, Sukoharjo, Indonesia \\ ${ }^{2}$ STIKES Karya Putra Bangsa Tulungagung, Central Java, Indonesia \\ Jl. Raya Tulungagung-Blitar KM 4, Sumbergempol-Tulungagung, East Java, Indonesia \\ ${ }^{3}$ Department of Pharmacology and Clinical Pharmacy, Faculty of Pharmacy, \\ Universitas Gadjah Mada, \\ Jl. Sekip utara, Sleman Yogyakarta, Indonesia
}

\begin{abstract}
Acquired Immuno Deficiency Syndrome (AIDS) is an infection caused by the Human Immunodeficiency Virus (HIV). The antiretrovirals (ARVs) combination is the basis for the management of therapy in HIV/AIDS patients, but it often raises problems like adverse drug reactions (ADRs). This study was conducted to determine the risk factors for the occurrence of ADRs in the use of first-line ARVs. It employed a cross-sectional design with retrospective data collection in patients visiting the Voluntary Cell Counting (VCT) room of RSUD Dr. Moewardi in November-December 2018. The data collected were sociodemographic, behavioral, and clinical characteristics, laboratory test results, and ARV profiles. Findings show that the risk factors for ADRs in the use of first-line ARVs are CD4 of $<200$ and 0-24 months of taking ARVs.
\end{abstract}

Keywords: risk factors for ADRs, HIV, antiretrovirals

\footnotetext{
*Corresponding author:

Fita Rahmawati

Department of Pharmacology and Clinical Pharmacy

Faculty of Pharmacy, Universitas Gadjah Mada

Jl. Sekip Utara, Sleman Yogyakarta Indonesia

Email: rahmawati_f@ugm.ac.id
} 


\section{INTRODUCTION}

Acquired immune deficiency syndrome (AIDS) is a disease caused by infections by the human immunodeficiency virus (HIV). HIV does not directly cause death but decreases body immunity instead, resulting in susceptibility to opportunistic infections (Ibrahim and 2017). Antiretrovirals (ARVs) combination is the basic principle of antiretroviral therapy for HIV/AIDS patients because it can reduce resistance, effectively suppress HIV replication, opportunistic infections, and other complications, and improve the quality and life expectancy of HIV/AIDS patients. Early therapy can protect the immune system from HIV-induced damages (Masenyetse et al., 2015).

Problems arising from the use of ARVs include adverse drug reactions or ADRs ( $\mathrm{Li}$ et al., 2017). This research is expected to help monitor and report the occurrence and risk factors of ADRs in patients receiving first-line antiretroviral therapy in Dr. Moewardi hospital.

\section{METHOD}

This research has been granted with an ethical clearance No. 758/XI/HREC/2018. It used a cross-sectional design with retrospective data collection in patients who visited the Voluntary Cell Counting (VCT) room of RSUD Dr. Moewardi, Surakarta, Indonesia, in November-December 2018. These data were sociodemographic, behavioral, and clinical characteristics, laboratory test results, and ARV profiles.

The research population was HIV-infected patients who received first-line ARV regimen therapy in the VCT room of RSUD Dr. Moewardi and met the inclusion and exclusion criteria. The inclusion criterion was the willingness to be involved in the study (participation was confirmed by filling out and signing an informed consent form). Meanwhile, the exclusion criteria were unstable mental conditions obtained from medical records (these conditions were believed to make them unable to provide information related to the perceived ADR) and age of $<18$ years (to facilitate the interview process). As a result, 204 patients were selected as the research population. In this study, the sample size was determined using the proportion-based formula by (Lameshow et al., 1997).

$$
\mathrm{n}=\frac{\mathrm{N} \mathrm{Z} \mathrm{Z}_{1}-\mathrm{a} / 2 \mathrm{pq}}{\mathrm{d}^{2}(\mathrm{~N}-1)+\mathrm{Z}^{2} 1-\alpha / 2 p q} \rightarrow \mathrm{n}=\frac{512 \times 1,960^{2} \times 0,667 \times 0,193}{0,1^{2} \times(512-1)+1,960^{2} \times 0,867 \times 0,193}=41 \text { people (minimum sample). }
$$

where:

$\begin{array}{ll}\mathrm{n} & \text { : number of samples } \\ \mathrm{N} & \text { : number of population }\end{array}$

$\mathrm{Z}^{2} 1-\alpha / 2$ : standard normal distribution values (table Z) at 95\% confidence level (1960)

$\mathrm{p} \quad$ : estimated population proportion of $86.7 \%$ (Mendes et al., 2018)

q $\quad: 1-\mathrm{p}(1-0.867=0.133)$

d : tolerable errors (absolute) $(0.1)$

This calculation yielded a minimum of 41 samples.

The research variables included independent and dependent variables. An independent variable is a variable that influences or causes a change in the appearance of a dependent variable. A dependent variable is a variable that is affected or appears because of the independent variable. In this study, the independent variables were sociodemographic, behavioral, and clinical characteristics, laboratory test results, and antiretrovirals (ARVs) profiles, while the dependent variable was the occurrence of ADRs. The first interview was intended to find out ADRs using the Naranjo algorithm-based questionnaire of the ADR probability scale (Badan Pengawas Obat dan Makanan Republik Indonesia, 2012) and conducted when participants visited the Voluntary Counseling and Testing (VCT) room. During which, information on patient characteristics, clinical characteristics, laboratory test results, and ARV profiles was gathered using patients data collection sheets. The second to fourth interviews were conducted by phone once a week using the same questionnaire to find out any occurrences of ADRs 
(Badan Pengawas Obat dan Makanan Republik Indonesia, 2012), with the help of the Medical Doctor in Charge (MDIC) of the VCT room.

\section{Data Analysis}

Answers recorded in the questionnaires were then analyzed in the Statistical Package for Social Sciences (SPSS) v.20 program. A univariate analysis was performed to define the distributions of sociodemographic, behavioral, and clinical characteristics, laboratory test results, and ARV profiles. Meanwhile, a bivariate analysis was conducted to explore the correlation between ADRs and their risk factors using the Chi-square or Fisher's exact tests (if the Chi-square test did not meet the expected count value), with $p$-values of $\leq 0.05$ indicating a significant correlation. The analyses were carried out at $5 \%$ confidence level $(\alpha=0.05)$, with a $95 \%$ confidence interval.

\section{RESULT AND DISCUSSION}

Adverse Drug Reactions are expressions of intrinsic intolerance to the accumulation of substances that are considered toxic. In this study, there were 204 patients, 176 of which (86\%) experienced ADRs, while the remaining 28 patients (14\%) did not. These results are similar to Kumari et al. (2017), i.e., patients who experienced ADRs have a larger proportion (228 people, $81.4 \%$ ) than those who did not (52 people, 18.6\%). The types of ADRs detected in this study were anemia, neutropenia, myopathy, dyspepsia, nausea, vomiting, kidney toxicity, drowsiness, insomnia, weight loss, dizziness, hepatotoxicity, rash, and pruritus.

\section{ARV profiles}

Zidovudine (AZT) is the first choice of drug in the combination of first-line ARV regimens because AZT is known to be well-tolerated and available in many combination preparations (FixedDose Combination). The most used combination is Zidovudine + Lamivudine + Nevirapine/Efavirenz because it is the first choice set by the Indonesian government for patients who do not have abnormalities in their liver and blood function. Lamivudine is the first choice of the NRTI class because it is safe, effective for hepatitis B, and widely available, including in a fixed-dose combination. The second choice from the NRTI class is Zidovudine because its side effects are generally easily tolerated and it rarely causes metabolic complications. Meanwhile, tenofovir in ARV regimens functions as a substitute for the previous ARV regimens. Antiretroviral replacement in patients can be prompted by toxicity reasons, where patients are unable to overcome the ADR from previous drugs, or by a failure of previous therapy, as evident from CD4 values (disease progression) (Hidayati et al., 2016). The result of ARV profiles can be seen in Table 1.

Table 1. Characteristics of antiretrovirals (ARVs) received by HIV patients in RSUD Dr. Moewardi in November-December 2018

\begin{tabular}{lccc}
\hline Characteristics of ARVs & $\begin{array}{c}\text { Number of patients } \\
\mathbf{N = \mathbf { 2 0 4 }}\end{array}$ & $\begin{array}{c}\text { Number of patients } \\
\text { experiencing ADRs } \\
\mathbf{N = \mathbf { 1 7 6 }}\end{array}$ & $\begin{array}{c}\text { Percentage of ADR } \\
\text { occurrences \% }\end{array}$ \\
\hline Types of ARV used & 93 & 77 & \\
AZT/3TC/NVP & 58 & 51 & 82.7 \\
AZT/3TC/EFV & 9 & 9 & 87.9 \\
TDF/3TC/NVP & 44 & 39 & 100.0 \\
TDF/3TC/EFV & 17 & & 88.6 \\
Durations of ARV use & 38 & 17 & 100.0 \\
1-6 months & 48 & 37 & 97.3 \\
7-12 months & 36 & 41 & 85.4 \\
13-24 months & 65 & 31 & 86.1 \\
25-36 Months & $34 \pm 26$ & 50 & 76.9 \\
$\geq 37$ months & & $32 \pm 26.9$ & \\
Mean \pm SD* & & & \\
\hline
\end{tabular}


These results are consistent with Eluwa et al. (2012), which suggested that the highest likelihood of ADRs is in the first six months of ARV use. (Namme Luma et al., 2012) proved that 1 of 5 patients (19.5\%) taking antiretroviral drugs experienced ADRs after less than one month of their antiretroviral therapy. Also, Tadesse et al. (2014) explained that ADRs occurred in 66\% of patients taking ARVs for $\leq 1$ month and in 51.7\% of patients taking ARVs for $>1$ month.

\section{Sociodemographic characteristics}

In this study, male HIV patients were higher in number than their female counterparts. This finding is similar to the data of the Directorate General of Disease Prevention and Control (Direktorat Jenderal Pencegahan dan Pengendalian Penyakit, 2017), i.e., the ratio of male to female HIV patients is 2:1. HIV/AIDS cases in men are higher because it is believed to be associated with sexual behavior as a precursor of transmission to and from commercial sex workers (CSWs) and men who have sex with men (MSM). Men reportedly exhibit more of this behavior compared to women (Butarbutar et al.,2014; Yuliandra et al., 2017). Table 2 show us the sociodemographic characteristics of HIV patients at RSUD Dr.Moewardi in November-December 2018.

Table 2. The sociodemographic characteristics of HIV patients at RSUD Dr. Moewardi in November-December 2018

\begin{tabular}{lccc}
\hline \multicolumn{1}{c}{$\begin{array}{c}\text { Sociodemographic } \\
\text { characteristics }\end{array}$} & $\begin{array}{c}\text { Number of patients } \\
\mathbf{N}=\mathbf{2 0 4}\end{array}$ & $\begin{array}{c}\text { Number of patients } \\
\text { experiencing ADRs } \\
\text { N= 176 }\end{array}$ & $\begin{array}{c}\text { Percentage of ADR } \\
\text { occurrences\% }\end{array}$ \\
\hline Sex & & & 87.4 \\
Male & 127 & 111 & 84.4 \\
Female & 77 & 65 & 86.3 \\
Age & 191 & 165 & 84.6 \\
$<60$ years & 13 & 11 & \\
$\geq 60$ years & $40.7 \pm 10.8$ & $40 \pm 10.5$ & 87.5 \\
Mean \pm SD & & & 81.8 \\
Marital Status & 160 & 140 & 81.8 \\
Married & 44 & 36 & 87.5 \\
Single & & & 89.0 \\
Education & 33 & 27 & 82.5 \\
Primary school & 40 & 35 & \\
Junior high school & 91 & 81 & \\
Senior high school & 40 & 33 & \\
Bachelor & & & \\
\hline \multicolumn{2}{l}{ SD: Standard } & & \\
\hline
\end{tabular}

\section{SD: Standard Deviation}

Based on age, the sampled patients were categorized into two categories, namely, adult (17-59 years old) and elderly ( $\geq 60$ years old). Sociodemographically, a larger share of the patients was adult, ranging from the youngest, 19, to the oldest, 78. Butarbutar et al. (2014) explain that the number of HIV/AIDS cases is high in the adult group, i.e., sexually active and productive age range.

A total of 160 sampled patients were married, which were larger than the unmarried ones. This result is similar to Anwar et al. (2018), which explained that HIV cases are found in a more substantial number in married patients (75.8\%). In this context, being married increases the risk of transmission of HIV infection through sexual contact and from mothers to their children during pregnancy, birth, and breastfeeding.

Patients with an upper secondary educational level, i.e., senior high school (SMA), contributed the highest to cases of HIV/AIDS, which amounted to 91 patients. Meanwhile, the least cases were found in those with a lower secondary educational level (elementary school; SD), which was up to 33 patients. HIV/AIDS affected all levels of education. Someone with high educational attainments that assumably have good knowledge of HIV/AIDS does not necessarily stay away from the spread of HIV 
infection (Butarbutar et al., 2014). Similarly, Kambu et al. (2016) signify the absence of a significant relationship between education level and transmission prevention measures.

\section{Behavioral Characteristics}

Among the sampled patients, 11 were illegal users of narcotics and psychotropic drugs. Compared to those who were not, the prevalence of ADRs in this group was higher (90.9\%). This result is inconsistent with Pádua (2006), where ADRs were identified more in patients who used drugs illegally (92 people, 34.7\%) than those who did not (28 people, 28.9\%). Drug abuse can cause unfavorable interactions with ARVs, leading to changes in ARV absorption and metabolism (Mendes et al., 2018). Behavioral characteristics can be seen in Table 3.

Table 3. The characteristics of the behavior of HIV patients at RSUD Dr. Moewardi in November-December 2018

\begin{tabular}{lccc}
\hline Behavioral Characteristics & $\begin{array}{c}\text { Number of patients } \\
\mathbf{N}=\mathbf{2 0 4}\end{array}$ & $\begin{array}{c}\text { Number of patients } \\
\text { experiencing ADRs } \\
\mathbf{N}=\mathbf{1 7 6}\end{array}$ & $\begin{array}{c}\text { Percentage of ADR } \\
\text { occurrences\% }\end{array}$ \\
\hline Drug users & 11 & 10 & \\
Yes & 193 & 166 & 80.9 \\
No & & & 86.0 \\
Alcohol users & 23 & 19 & 82.6 \\
Yes & 181 & 157 & 86.7 \\
No & & & \\
\hline
\end{tabular}

ADRs appeared in patients who consumed alcohol (19 people) and those who did not (157 people). ADRs were found in a large proportion of the latter $(86.7 \%)$, which was higher in percentage than the former. In antiretroviral therapy, both alcohol and drug abuse can lead to pharmacokinetic interactions because these substances are all metabolized in the liver. Drug interactions are a precursor of ADRs; therefore, extra cautions are needed when prescribing ARVs for patients with liver dysfunction. In this context, controlling potential pharmacokinetic interactions can include the medical team providing counseling that recommends patients to reduce or stop using alcohol and drugs illegally as an attempt to reduce the probability of ADRs (Pádua, 2006).

\section{Clinical characteristics}

Among the 204 sampled patients, 52 were co-infected and 152 were not co-infected. Most coinfection was tuberculosis (TB, in 45 people), while hepatitis co-infection was the least (7 people). These results are similar to Butarbutar et al. (2014), which stated that the most frequent co-infection is tuberculosis infection (48.8\%). TB is associated with damages to the cellular immune system; hence, TB infection can attack HIV patients very easily (Butarbutar et al., 2014), leading to a high rate of TB co-infection. The results about clinical characteristic of HIV patients can be seen in Table 4.

Table 4. Clinical characteristics of HIV patients at RSUD Dr. Moewardi in NovemberDecember 2018

\begin{tabular}{lccc}
\hline $\begin{array}{c}\text { Clinical } \\
\text { characteristics }\end{array}$ & $\begin{array}{c}\text { Number of patients } \\
\mathbf{N = \mathbf { 2 0 4 }}\end{array}$ & $\begin{array}{c}\text { Number of patients } \\
\text { experiencing ADRs } \\
\mathbf{N = 1 7 6}\end{array}$ & $\begin{array}{c}\text { Percentage of } \\
\text { ADR } \\
\text { occurrences\% }\end{array}$ \\
\hline $\begin{array}{l}\text { Co-infections } \\
\text { TBC }\end{array}$ & 45 & 38 & 84,4 \\
Hepatitis & 7 & 7 & 100,0 \\
\hline
\end{tabular}

ADRs were detected in 38 patients with TB co-infection and 7 patients with hepatitis coinfection. However, the percentage shows that ADRs were more prevalent in patients with hepatitis 
co-infection (100\%) than the ones with tuberculosis. In antiretroviral therapy, hepatitis is a common ADR due to the use of anti-tuberculosis drugs, and liver function is reportedly improves after patients no longer take these drugs (Rimfampicin). Anti-tuberculosis drugs can contribute to ADRs, and these types of reactions account for $28.3 \%$ of the total ADR cases (Kumar et al., 2015). Drugs administered for co-infection therapy can increase the probability of ADRs due to cumulative toxicity or drug interactions. Opportunistic hepatitis or tuberculosis infections with the use of antiretroviral drugs can increase the risk of hepatotoxicity (Prosperi et al., 2012).

\section{Laboratory test results}

Among the sampled patients, 141 had CD4 counts of $>200$ cells $/ \mathrm{mm}^{3}$, which was larger than the number of patients with CD4 $<200$ cells $/ \mathrm{mm}^{3}$. In this study, CD4 counts ranged from 5 to 786 cells $/ \mathrm{mm}^{3}$, with an average of 286.1 cells $/ \mathrm{mm}^{3}$. Table 5 show us Characteristics of laboratory test results of HIV patients at RSUD Dr. Moewardi in November-December 2018.

Table 5. Characteristics of laboratory test results of HIV patients at RSUD Dr. Moewardi in November-December 2018

\begin{tabular}{lccc}
\hline Laboratory test results & $\begin{array}{c}\text { Number of patients } \\
\mathbf{N}=\mathbf{2 0 4}\end{array}$ & $\begin{array}{c}\text { Number of patients } \\
\text { experiencing ADRs } \\
\mathbf{N}=\mathbf{1 7 6}\end{array}$ & $\begin{array}{c}\text { Percentage of ADR } \\
\text { occurrences\% }\end{array}$ \\
\hline CD4 & 63 & 59 & \\
$\leq 200$ & 141 & 117 & 93.6 \\
$>200$ & $286.1 \pm 155.3$ & $278.4 \pm 156.4$ & 82.9 \\
Mean \pm SD $^{*}$ & & & \\
\hline
\end{tabular}

This result is similar to Lartey et al. (2014), where CD4 counts of more than 250 cells $/ \mathrm{mm}^{3}$ are associated with a reduced number of ADR cases. Similarly, Mendes et al. (2018) confirm that patients with CD4 counts of $<200$ cells $/ \mathrm{mm}^{3}$ have to receive additional drugs to prevent opportunistic infections, increasing the occurrences of ADRs.

\section{Risk factors for adverse drug reactions (ADRs)}

Risk factors are conditions that influence the development of certain diseases or health status. In this study, the CD4 count was found to be significantly correlated with ADRs, as evidenced by pvalue $<0.05$. Patients with CD4 $<200$ cells $/ \mathrm{mm}^{3}$ had 3.026 times higher risks of experiencing ADRs than patients with CD4 $>200$ cells $/ \mathrm{mm}^{3}$. These results are similar to Modayil and Harugeri (2011), which also confirm the significant relationship between CD4 counts and ADRs ( $p=0.025$ ). Eluwa et al. (2012) and Tatiparthi and Mamo (2015) correlate low CD4 counts to the occurrences of ADRs in most patients with $<200$ cells $/ \mathrm{mm}^{3}$. Risk Factors for ADRs in the First-Line ARV therapy can be seen in Table 6. 
Table 6. Risk factors for ADRs in the first-line ARV therapy

\begin{tabular}{|c|c|c|c|c|}
\hline \multirow{2}{*}{ Characteristics } & \multicolumn{2}{|c|}{ Adverse drug reactions } & \multirow[t]{2}{*}{ P-value } & \multirow{2}{*}{ OR (CI 95\%) } \\
\hline & Yes & No & & \\
\hline \multicolumn{5}{|l|}{ Gender } \\
\hline Male & $111(63.1)$ & $16(57.1)$ & & \\
\hline Female & $65(36.9)$ & $12(42.9)$ & 0.548 & $1.281(0.571-2.875)$ \\
\hline \multicolumn{5}{|l|}{ Age } \\
\hline$<60$ years & $165(93.8)$ & $26(92.9)$ & & \\
\hline$\geq 60$ years & $11(6.2)$ & $2(7.1)$ & $0.694 *$ & $1.154(0.242-5.504)$ \\
\hline \multicolumn{5}{|l|}{ CD4 counts } \\
\hline$\leq 200$ & $59(33.5)$ & $4(14.3)$ & & \\
\hline$>200$ & $117(66.5)$ & $24(85.7)$ & 0.041 & $3.026(1.003-9.124)$ \\
\hline \multicolumn{5}{|c|}{ Duration of ARV use } \\
\hline $0-24$ months & $95(54.0)$ & $8(28.6)$ & & \\
\hline$\geq 25$ months & $81(46.0)$ & $20(71.4)$ & 0.013 & $2.932(1.226-7.012)$ \\
\hline
\end{tabular}

* the Fisher's exact test

CD4 is a special type of lymphocytes most affected by the Human Immunodeficiency Virus (HIV). HIV is associated with a decrease in CD4 counts as it infects CD4 and causes the death of this cell once it enters the body. Lowered CD4 counts indicate the level of damage to the immune system, increasing the vulnerability of HIV-infected bodies to various types of diseases. CD4 examination is carried out together with the administration of the ARV regimen and once every six months as a reference for starting, controlling, and changing the regimen given. Data on CD4 counts before and during the ARV therapy can provide information on whether the therapy succeeds or fails (Anwar et al., 2018; Butarbutar et al., 2014).

HIV-infected patients with CD4 counts of averagely 50350 cells $/ \mathrm{mm}^{3}$ need to begin antiretroviral therapy immediately. If the CD4 count is $\leq 200$ cells $/ \mathrm{mm} 3$, Cotrimoxazole $1 \mathrm{x} 960 \mathrm{mg}$ was prescribed for two weeks to prevent opportunistic infections, followed by ARVs. Immunity can be evaluated by observing the average counts of CD4. After the administration of ARVs, the CD4 count of 70-100 cells $/ \mathrm{mm}^{3} /$ year can change to $50-100$ cells $/ \mathrm{mm}^{3} /$ year. Patients who have never reached CD4 counts of 100 cells $/ \mathrm{mm}^{3}$ or experienced a progressive decreased in CD4 counts after reaching a high count without any other medical conditions are suspected for immunological failure. Immunological failure in the ARV therapy occurs in three patterns: (1) CD4<100 cells $/ \mathrm{mm}^{3}$ after one year of ARV therapy, (2) after one year of therapy, the CD4 count recovers or becomes lower than at the beginning of the therapy, and (3) CD4 count decreases to 50\% of the highest CD4 count ever reached during the therapy. Changes are made to current antiretroviral therapy if the CD4 count remains at <200 cells $/ \mathrm{mm}^{3}$ during one year of the therapy (Kementerian Kesehatan Republik Indonesia - Direktorat Jenderal Pengendalian Penyakit dan Penyehatan Lingkungan, 2011).

This study shows that the length of ARV therapy is significantly related to the occurrences of ADRs, as apparent from p-value $<0.05$. Prolonged use of ARVs, 0-24 months, creates 2.932 times higher risk of experiencing ADRs compared to patients having taken ARVs for 25 months. These results are similar to Eluwa et al. (2012), which found that ADRs are most likely to occur during the first six months of ARV therapy. Early use of antiretroviral drugs before CD4 counts decline and opportunistic infections occur can reduce ADRs (Lartey et al., 2014). 


\section{CONCLUSION}

Adverse Drug Reactions (ADRs) have been found in 176 sampled patients (86\%) but not in the other 28 patients $(14 \%)$. The significant risk factors for ADRs in the use of first-line ARVs are CD4 counts $<200$ cells $/ \mathrm{mm}^{3}$ and $0-24$ months of taking antiretroviral drugs.

\section{ACKNOWLEDGMENT}

Our gratitude extends to Zakky Cholisoh, M. Clin., Pharm., PhD., Apt, Prof. Dr. dr. EM. Sutrisna, M.Kes, and patients in the VCT room of RSUD Dr. Moewardi who were willing to participate in this research.

\section{REFERENCES}

Anwar, Y., Nugroho, S. A., \& Tantri, N. D. (2018). Karakteristik Sosiodemografi, Klinis, dan Pola Terapi Antiretroviral Pasien HIV/AIDS di RSPI Prof. Dr. Sulianti Saroso Periode Januari-Juni 2016. Pharmaceutical Journal of Indonesia, 15(1), 72-89.

Badan Pengawas Obat dan Makanan Republik Indonesia. (2012). Pedoman monioring efek samping obat (MESO) bagi tenaga kesehatan. Pedoman Monitoring Efek Samping Obat (MESO) bagi Tenaga Kesehatan.

Butarbutar, Tugomaito, J., Lubis, Rahayu, \& Hiswani. (2014). Karakteristik penderita HIV/AIDS Di RSUD Dr. Djasamen Saragih Pematangsiantar tahun 2013-2014, 1-7.

Direktorat Jenderal Pencegahan dan Pengendalian Penyakit. (2017). Laporan perkembangan HIV/AIDS 7 penyakit menular seksual (PIMS) triwulan I tahun 2017 (pp. 1-402).

Eluwa, G. I., Badru, T., Akpoigbe, K. J., Chabikuli, O., \& Hamelmann, C. (2012). Adverse drug reactions to antiretroviral therapy (ARVs): Incidence, type and risk factors in Nigeria. $B M C$ Clinical Pharmacology, 12(7), 1-9.

Hidayati, N. R., Abdillah, S., \& Keban, S. A. (2016). Analisis adverse drug reactions obat anti retroviral pada pengobatan pasien Hiv / Aids Di Rsud Gunung Jati Cirebon Tahun 2013. Pharmaciana, 6(1), 79-88.

Ibrahim, K., H, Y. K., Rahayuwati, L., Nurmalisa, B. E., \& Fitri, S. U. R. (2017). Hubungan antara fatigue, jumlah CD4, dan kadar hemoglobin pada pasien yang terinfeksi human immunodeficiency virus ( HIV ). Jurnal Keperawatan Padjadjaran, 5, 271-280.

Kambu, Y., Waluyo, A., \& Kuntarti. (2016). Umur orang dengan HIV/AIDS (ODHA) berhubungan dengan tindakan pencegahan penularan HIV. Journal Keperawatan Indonesia, 19, 200-207.

Kementerian Kesehatan Republik Indonesia - Direktorat Jenderal Pengendalian Penyakit dan Penyehatan Lingkungan. (2011). Pedoman Nasional Tatalaksana Klinis Infeksi HIV dan Terapi Antiretroviral pada Orang Dewasa. Jakarta.

Kumar Jha Anshu, Gadgade, A., K.Shenoy, A., Chowta, M. N., \& John T. Ramapuram. (2015). Evaluation of adverse drug reactions in HIV positive patients in a tertiary care hospital. Perspectives in Clinical Research, 6, 34-38.

Kumari, R., Chandra, S., Gari, M., \& Kumari, A. (2017). An assessment of adverse drug reaction patterns among HIV positive patients receiving antiretroviral therapy in a tertiary care hospital. International Journal of Pharmacological Research, 7, 88-93.

Lameshow, S., Hosmer, D. W., \& Klar, J. (1997). Besaran sampel dalam penelitian kesehatan. Gadjah Mada University Press.

Lartey, M., Essel, A., Asante-Quarshie, A., Kenu, E., Ganu, V., \& Neequaye, A. (2014). adverse drug reactions to antiretroviral therapy during the early art period at a tertiary hospital in Ghana. Pan African Medical Journal, 18, 1-6.

Li, H., Marley, G., Ma, W., Wei, C., Lackey, M., Ma, Q., ... Tucker, J. D. (2017). The role of ARV associated adverse drug reactions in influencing adherence among HIV-infected individuals: A systematic review and qualitative meta-synthesis. AIDS and Behavior, 21, 341-351. 
Masenyetse, L. J., Manda, S. O. M., \& Mwambi, H. G. (2015). An assessment of adverse drug reactions among HIV positive patients receiving antiretroviral treatment in South Africa. AIDS Research and Therapy, 12, 1-8.

Mendes, J. C., Bonolo, P. D. F., Ceccato, M. D. G. B., Costa, J. D. O., Reis, A. M. M., Dos Santos, H., \& Silveira, M. R. (2018). Adverse reactions associated with first-line regimens in patient initiating antiretroviral therapy. European Journal of Clinical Pharmacology, 1-12.

Modayil, R. R., Harugeri, A., Parthasarathi, G., Ramesh, M., Prasad, R., Naik, V., \& Giriyapura, V. (2011). Adverse drug reactions to antiretroviral therapy ( ART ): an experience of spontaneous reporting and intensive monitoring from ART centre in India. Pharmacoepidemiology and Drug Safety, 19(3), 247-255.

Namme Luma, H., Doualla, M.-S., Choukem, S.-P., Temfack, E., Ashuntantang, G., Achu Joko, H., ... Koulla-Shiro, S. (2012). Adverse drug reactions of Highly Active Antiretroviral Therapy (HAART) in HIV infected patients at the General Hospital, Douala, Cameroon: a cross sectional study. The Pan African Medical Journal, 12(87), 1-7.

Pádua, C. A. M. De. (2006). High incidence of adverse reactions to initial antiretroviral therapy in Brazil. Brazilian Journal of Medical and Biological Research, 495-505.

Prosperi, M. C. F., Fabbiani, M., Fanti, I., Zaccarelli, M., Colafigli, M., Mondi, A., ... Giambenedetto, S. Di. (2012). Predictors of first-line antiretroviral therapy discontinuation due to drug-related adverse events in HIV-infected patients : a retrospective cohort study. BMC Infectious Disease.

Tadesse, W. T., Mekonnen, A. B., \& Tesfaye, W. H. (2014). Self-reported adverse drug reactions and their influence on highly active antiretroviral therapy in HIV infected patients : a cross sectional study, 15, 1-9.

Tatiparthi, R., \& Mamo, Y. (2015). Prevalence of ADRs and associated factors of antiretroviral treatment on HIV positive adults at jush. Indian Journal of Pharmacy Practice, 7, 8-15.

Yuliandra, Y., Nosa, U. S., Raveinal, \& Almasdy, D. (2017). Terapi antiretroviral pada pasien HIV / AIDS di RSUP . Dr . M . Djamil Padang: kajian sosiodemografi dan evaluasi obat. Jurnal Sains Farmasi \& Klinis, 4(1), 1-8. 
